\section{MODERNIST THAI SHORT STORIES, 1964-1973: THE RELATIONSHIP WITH ART ${ }^{1}$}

\author{
Soranat Tailanga ${ }^{2}$
}

\begin{abstract}
A number of distinguished Thai short stories from 1964 to 1973 reveal new and distinctive features in terms of subject, form, concepts and style. These features are similar to those of modernism, which was an international movement in literature and the arts that began in the late $19^{\text {th }}$ century and continued into the early $20^{\text {th }}$ century. The similarity suggests the direct and indirect influences of the modernist style upon Thai writers. Furthermore, the change in style of some of the short stories indicates a relationship with the art movements: impressionism, expressionism, cubism and surrealism, which were subsidiary art movements within modernism. These specific features of the Thai short story signify a radical break with the traditional writing of the time.
\end{abstract}

\section{Introduction}

Generically, the term "modernism" refers to a type of position or attitude characterized by specific forms of response towards modernization and

\footnotetext{
${ }^{1}$ The original version of this paper was presented at the International Conference on Thai Language and Literature: Wisdom and Dynamism in the Global Context, 10-12 November, 2006, Chulalongkorn University, Bangkok, Thailand.

${ }^{2}$ Associate Professor, Department of Literature, Faculty of Humanities, Kasetsart University
}

modernity. ${ }^{3}$ Science and technology have had a part to play in the rapid and continual change in every aspect. The unquestionable change was the modes of representation of the modern world. The attempt to offer alternative perception applied to literature, music, painting, film and architecture. These new modes were later called "modernism" and the term has been used to cover the international movement in the late $19^{\text {th }}$ century to the early twentieth century, or roughly from 1890 s to 1930 s.

In the area of art and literature, they attempted to come to terms with the urban, industrial and secular society that emerged during the $19^{\text {th }}$ century. They also abandoned realism, the style and concept that presents an accurate depiction of nature. Modern art and literature sought to free itself from the concept of mimesis or art as the reflection of nature. They needed no social or religious justification for its existence. Thus a "crisis of representation" occurred when the entire mode of existence within modernist experience became incompatible with the "traditional" decorum of realism at the time. It has been pointed out that modern artists used innovation in art forms. Charles Harrison defines the symptoms of the breakdown from realism as:

a tendency for the shapes, colors, and materials of art to lead a life of their own, forming unusual combinations, offering distorted or

\footnotetext{
${ }^{3}$ The term "modernization" here refers to the range of technological, economic, and political processes associated with the Industrial Revolution and its aftermath, while "modernity" refers to the social conditions and modes of experience that are seen as the effects of those processes (Harrison 1997: 6).
} 
exaggerated versions of the appearances of nature and, in some cases, losing all obvious connection with the ordinary objects of our visual experience.

(Harrison 1997: 9)

The modern artists' experiments with color and space and their abandonment of representationalism might be compared with the practices of modern writers. In the West, the relationship between modern art and modern literature ${ }^{4}$ has been widely studied ${ }^{5}$. The modern writers also experimented with new style and technique as well as subject matter; and at times affinities with the modern art emerged. The reaction to the crisis of representation in literature arose in the form of technical innovation in various genres: the abandonment of traditional versification methods in free verse, stream of consciousness, which represents the thoughts of individual characters in narrative and the elimination of the separation between the stage and the audience in theatre (Lewis 2007: 3).

Such a crisis of representation can also be seen in Thai literature, especially in modernist Thai short stories. ${ }^{6}$ Starting in 1964 and continuing to 1973, the Thai literary circle saw the gradual appearance of innovative styles and content in writing as a counter attack to dictatorship and the established publications which

\footnotetext{
${ }^{4}$ In this article, I have used the terms 'modern' and 'modernism' interchangeably.

${ }^{5}$ See Edson 2000, Roston 2000, Schwarz 1997, Butler 1994, Torgonick 1985, Karl 1985, Steiner 1982

${ }^{6}$ Interested readers please see details of the characteristics of modernist Thai short stories in Tailanga 2005.
}

discriminated against the works of young writers.

In Thailand, because consecutive autocratic governments between 1958 and 1973 under the regimes of first Sarit Thanarat and then Thanom Kittikhachon exercised a rigid regulation of publication, freedom of speech was limited. Writers were forbidden to criticize the government's policies and administration. Thus, the Thai literary circle suffered decades of escapist literature, which aimed at entertainment. The 1960s saw Thai literature struggling to depart from "traditional" realist writing, both in content and style. Newcomers on the literary scene tried to find innovative styles of writing; however, their attempts failed because the established publishers accepted only works written by famous writers or those created according to their "standard" in the style of realism.

Suffering from the dictatorship and its regulation of publishing, a crisis of representation was felt. Students in universities ${ }^{7}$ started to realize that new ways of perception and presentation had to be explored. Consequently, they expressed themselves in certain activity groups such as book clubs, from where their literary magazines originated as early as 1961. From that time onwards, illegal student magazines or little magazines found their

\footnotetext{
${ }^{7}$ It should be remembered that the number of university students increased rapidly due to the Sarit Thanarat administration's education policy. The expansion in the number of undergraduate students was seen as crucial to the growth of capitalism and modernization (Phongphaichit and Baker 2003: 259). Later on in the 1960s these people, students and graduates, formed the new intellectual middle class and fought for democracy in 1973.
} 
voice and achieved significant growth. ${ }^{8}$ There were numerous little magazines and these were distributed by various student groups and clubs under changing titles, which was a way of avoiding the rigid control of publication. These little magazines offered a space where students could express their opinions and seek out audiences. At first, the works written by students were imitations of the literary fashion of the moment but later, creative and innovative literary works started to emerge in these little magazines.

Some of the students who had experience in producing the little magazines later managed to form groups and called themselves by different names; the most prominent ones were Phrachan Siao (Crescent Moon) ${ }^{9}$ and Num Nao Sao Suai (Handsome Guys, Pretty Girls). ${ }^{10}$ Since the number of students who shared these literary interests was quite small, these young people became acquainted and networking within the avant-garde literary circle was initiated with a little help from the established magazines like Sayamrat Weekly, and the Social Science Review, led by Suluk Siwalak, the first editor, and Suchart Sawatsi, the second. These magazines had an important role in supporting the avant-garde movement and

\footnotetext{
${ }^{8}$ In the West, notably in England and The United States, modernist works originally found their way into print through little magazines. These magazines, though limited in readership, created the new movements in literature and various arts (Bradbury and McFarlane 1985: 203).

${ }^{9}$ The group was set up at first by Thammasat students, but later included students from other universities such as Chulalongkorn University and Kasetsart University.

${ }^{10}$ The group was set up by Rong Wongsawan and friends who had graduated from Silpakorn University.
}

experimental writing ${ }^{11}$ and had a powerful impact upon academic circles. Another breakthrough in Thai publishing, notably created by Num Nao Sao Suai, was the birth of modern style pocket books in 1969. This kind of publication was innovative for both its content and artistic style.

This innovative writing appeared mostly in the form of the short story. By 1964, short stories were exhibiting radical changes in their content and form. These works, which dared to experiment with new styles, were far more sophisticated than those of the standard publishing houses. For example, The White Balloon (ลูกโป่งสี ขาว) and The Glassless Spectacles (แว่นตา ไม่มีกระจก) by Niphon Chittakam, then a student at Silpakorn University, were milestones of the surrealistic style. Other stylistically creative "modern" stories also showed the influence of art.

The present study, then, is an attempt to show that there was a close relationship between Thai short stories and modernist art. The first aspect of that relationship is simply the reference to art movements, artists and particular paintings and sculptures mentioned in the stories. The second is the adaptation of art styles and techniques into writing, which shows that, for Thai writers, experimentation in modern art exhibited a response to the social and cultural crisis of their era.

\footnotetext{
${ }^{11}$ Suluk Siwalak initiated an activity group called "Paritat Sewana," which implanted liberal ideas among students whereas Suchart Sawatsi, as editor of The Social Science Review at one period, published a large number of avant-garde poems and short stories.
} 


\section{The artists as writers}

It is noteworthy that the writers of modern short stories written from 1964 to 1973 were art graduates or art lovers: Suwanni Sukhontha, Niphon Chittakam and Ditha Ketwiphat graduated from Silpakorn University; Surachai Chantimathon studied art at an art school but did not graduate; Khomson Khunadilok and Suwat Srichuea studied at technical colleges; Thanong Phisan graduated from Chulalongkorn in engineering but was interested in art; ${ }^{12}$ and Suchart Sawatsi, an art lover, graduated in history from Thammasat University and later became an artist himself. So it was quite natural that these writers were influenced by art in more ways than one.

As these writers were art students or art lovers, they were prone to mention paintings, art styles, painters, and sculptors in their stories. Some writers applied the styles of various art movements to their writing, creating innovation in Thai literature.

The relationship between modern Thai literature and art in Thailand can be traced back to the establishment of the School of Fine Arts, since many writers were either graduates of this institution or students and admirers. An education in Western arts was formally introduced to Thailand through the collaboration of Professor Silpa Bhirasri, an Italian artist, and the chief of the Architecture Division of the Fine Arts Department. In 1933, the Fine Arts School was established, and two years later its name was changed to the Art Section of the School of Fine Arts. In 1943, Silpakorn University was established and the first subjects taught in the institution

${ }^{12}$ Interview with Pisan on May 16, 2006 were painting and sculpture (Department of Fine Arts 1993: 31).

The curriculum and teaching strategies and techniques were the same as those of the Academy in Florence, Silpa Bhirasri's alma mater. Students were not encouraged to practise modern art since the professor emphasized the Academy's teaching techniques. Students who painted in a modernist style usually received strong criticism and low grades from the professor.

It was not until around 1961 that modern art was fully accepted in art circles; impressionism, cubism, futurism and abstract expressionism became widely known and practised (Chaiprasathna 1996: 13). But as late as 1971, Chalut Nimsamoe, a renowned painter and a student of Professor Silpa Bhirasri, wrote an article pointing out that Thai art was more than 50 years behind the Western art. The realistic style had become firmly established whereas abstract art had only just been introduced to Thailand.

After Silpakorn University, numerous art schools were established all over Thailand and interest in art flourished and became more widespread since a large number of art students graduated from these schools over the years.

This is not to say that modernist innovative styles came only through the study of art. Numerous Thai writers were also influenced by Western literature, both directly by reading, and indirectly through formal and informal discussion among friends (Chiangkun 1990: 28, Pholanan 2003: 146). 


\section{Reference to art}

One of the most interesting characteristics of the Thai short stories of the period is their reference to art movements, artists and art works. Suwanni Sukhontha, who had been an art lecturer at Silpakorn University before becoming a professional writer, was one of the writers who now and then referred to modern art and artists in her works. In Red Bougainvillea and Romance (เฟื่องฟ้าแดงกับเรื่องรัก ๆ ใคร่ ๆ), which is a story of the unfulfilled love of a middle-aged woman, the narrator tries to catch a butterfly in vain. She compares this attempt to the capture of a hard-toreach object and the invisible: it was like trying to touch mist or clouds, or the sweetness in poetry, or to grasp the beauty in Rodin's ${ }^{13}$ The Kiss (Sukhontha 1982: 150). The story compares the catching of a butterfly with a hard-to-reach "object" (which implies love in the story) and with the aesthetics of poetry and Rodin's specific work, The Kiss.

In Lonesome Wine in an Old-fashioned Glass (ไวน์เปลี่ยวในแก้วโอลด์แฟชั่น), the protagonist, a middle-aged woman, is drinking by herself in a restaurant. Being alone, her thoughts wander according to what she sees. As she is looking at the surroundings, the types of plants in particular, she thinks of the paintings of Henri Rousseau, a modern French painter whose eminent works depict tropical scenes: The bon plants were growing abundantly. The color of their leaves was deep green; their brown stalks were smooth, like the arm of a teenager. The image of the plants looked mysterious like

\footnotetext{
${ }^{13}$ Auguste Rodin (1840-1917) was a French sculptor whose famous works are The Kiss and The Thinker.
}

Rousseau's paintings (Sukhontha 1982: 298). In this story, instead of a mere comparison of the mysterious quality of the plants in the traditional way, the writer compares it to "Rousseau's paintings."

To appreciate the comparisons in these stories and to conjure up the images, the reader, then, is required to have a specific knowledge of modernist artists' works.

Like Suwanni Sukhontha, Surachai Chantimathon refers to art, paintings and artists in many of his short stories. The story titled The Season of Withering Flowers (ฤดูดอกไม้โรย) is a letter written by an art student to a friend. He complains about his school, friends and the ignorance of art of people in general. He talks about people who refuse to open their minds to abstract art as a new style of painting and claims that these people are "the destroyers of art." Elsewhere in the same story, he talks about a friend who has written a poem on a painting called The Persistence of Memory by Salvador Dali, whereas in Sangkhara (Constitution), the protagonist compares the body of a prostitute with the bodies of the women in paintings by Pierre Auguste Renoir. ${ }^{14}$ Again, the reader is expected to have some knowledge of the artist and his works.

Thanong Phisan, then an engineering student at Chulalongkorn University, included the life and works of Vincent van $\operatorname{Gogh}^{15}$ in two of his stories, The Love Story of Ram and Rawi (เรื่องรักของแรมและ ราวี) (Ruam Rueang San Doi Num Nao Lae Prachan Siaw 1971) and From the Urinecolored Room (จากห้องสีปัสสาวะ) (Sawatsi

\footnotetext{
${ }^{14}$ French impressionist painter

${ }^{15}$ Dutch post-impressionist painter
} 
1975). The first story mentions the first post-impressionist exhibition in England in $1910 .{ }^{16}$ The narrator in the story argues that the post-impressionists provide an example of the abandonment of realism. This elimination of traditional perspective and styles was rejected at first but later these innovative new styles of art became widely accepted. The narrator thus refers to the 1910 exhibition to show that the rejection of "tradition." and the implantation of the "new" in a society is difficult but worthwhile and that one should have the willpower to fight against all odds. In the second story, characters discuss the life and paintings of Vincent van Gogh.

These references to art can mostly be found in impressionistic ${ }^{17}$ works where the characters become lost in their thoughts and contemplate their surroundings. Since these works are expressions of thought, it is clear that in this period Thai writers began to experiment with the writing technique of the unmediated presentation of thoughts, that is, without a narrator acting as a mediator who recounts what is in the character's mind.

\footnotetext{
${ }^{16}$ The first post-impressionist exhibition in England was organized by Roger Fry and called "Manet and the post-impressionists." This exhibition provided an example for the abandonment of realism and the launch of European modern art in England. Virginia Woolf wrote that On or About December 10, 1910 Human Character Changed to mark the revolution in art styles (Stevenson 1992: 7).

${ }^{17}$ In impressionistic works, materials are presented as they appear to the individual temperament at a precise moment and from a particular vantage point rather than as they are presumed to be in actuality (Holman and Harmon 1992: 93, 244).
}

In these stories, the references to art are more or less specific, for they refer to particular painters and paintings. For general readers who have no knowledge of art, these references are insignificant and meaningless because the readers cannot appreciate the imagery through an association with particular paintings. It may be possible that these writings aimed to communicate with a certain audience, people who had an interest in common with the authors, since they were published in "liberal" or little magazines, the readership of which were interested in new writing styles.

\section{The influence of a modern painting: Where do we come from? What are we? Where are we going?}

When reading modern Thai short stories, the reader may be amazed when coming across the questions in many short stories: Where do we come from? What are we? Where are we going? These questions, slightly modified, are the title of a short story by Suchart Sawatsi: Where do we come from? How do we come here? Where are we going? (มาจากไหน? มาอย่างไร? จะไป ไหน?) (Sawatsi 1972). This story tells of the narrator finding 'a dead body' in a drawer and then trying to hide it somewhere else. On the way, he contemplates life and the questions are asked and answered in the story: Where do we come from? Nobody knows. Where are we going? Again, nobody knows. But first I have to get out of here... (Sawatsi 1972: 109). The questions appear once again in another short story called $A$ Walk to the Field (การเดินทางไปสู่ท้องทุ่ง) (Sawatsi 1972) written by the same author but this time they are found in a conversation between 
the protagonist and an imaginary woman. The story is about a man's visit to a field, which ends with his confrontation with a dead body being carried to a temple. The story can be interpreted as expressing the meaninglessness of life. Before starting his walk, his thoughts are about an imaginary woman who might be his companion in the walk. The woman asks him "Who are you?" and "Where do you come from?" (Sawatsi 1972: 123)

In To Die in the Sea (ไปตายทะเล) by Suwat Srichuea, the questions can be found again. In this story, the protagonist decides to drown himself in the sea because he is tired and cannot find a purpose for his life. But before doing this, he goes to a brothel. Later, he and a prostitute have a rather philosophical conversation:

Where do you come from?

she asked me.

I don't know, I answered.

Why are you here? she asked.

I don't know, I answered.

She looked upset.

Where are you going?

She asked me again.

I don't know, I answered

truthfully.

(Srichuea 1975: 10)

The questions arise again at the beginning of another short story, The Journey to the Inside (การเดินทางเข้าไปสู่ข้างใน) by Thanong Phisan. This time some information about the origin of these recurring questions is given:

The thunderous yet sad song was playing with strong beats, calling for a violent change of the world. This crude, melancholic, sincere song could be compared to a type of painting called "fauvism," where unrestrained feeling is expressed. I tried to find the meaning of the painting called "Where do we come from? What are we? Where are we going?" It was painted by an artist who searched for the meaning of art and life in the South Seas. Before creating this work he had seen the death of an empty and meaningless life. He then planned to commit suicide, which was what many might want to do. "Before I die, I will paint a big picture telling what I think." To his disappointment, the plan failed.

(Phisan 1972: 62)

The artist who painted the work called "Where do we come from? What are we? Where are we going?" 18 (painted between 1897-1898) was Paul Gauguin, a postimpressionist painter whose later style was called "fauvism." After a failed attempt to take his own life, Gauguin wanted to paint what he had confronted. The painting is of dramatic personae: children, figures, farm animals, old women and idols, who offer the symbolic interpretation of everyday life, destiny, death, and the beyond (Eisenman 1997: 135).

\footnotetext{
${ }^{18}$ Gauguin modified the title from Tolstoy's book called What Then Must We Do? (Russell 1981: 26).

${ }^{19}$ Fauves means 'wild beasts.' Fauvist paintings are known chiefly for their violently contrasting colors. The style is a combination of expressionism and impressionism (Atkins 1993: 100).
} 
The questions of the painting's title showed Gauguin's journey into the unknown world and expressed the opposition between the thinking of the European and the primitive. It is also a contemplation of the meaning of life. Thai writers were interested in these ontological questions of the painting's title. It should be noted that the questions asked in these stories cannot be answered or are left without attempting an answer. Being in a society under dictatorial restraint for more than a decade, the title must have led them to question the meaning and the purpose of life, which later culminated in one of the themes of this period. ${ }^{20}$ The stories concerned with the theme of the meaning of life and death, and suicide attempt include Surachai Chantimathon's The Dumb City (นครใบ้) (Chantimathon 1996), The Yellow

Bird (นกสีเหลือง) (Chantimathon 1996), and

The Music of the Dead (เพลงศพ) (Chantimathon 1997), Vittayakon Chiangkun's The Road that Leads to Death (ถนนสายที่นำไปสู่ความตาย) (Chiangkun 1990) and Kon Krailat's One Day at a Graveyard (วันหนึ่งที่สุสาน) (Krailat 1974), etc.

\section{The modification of art styles into writing}

In a piece of research called Surrealistic Trends in Paintings and Literature in

\footnotetext{
${ }^{20}$ Other themes of 1964-1973 Thai short stories are, for example, "the shattered entity in the modern city," "the isolated and alienated individual within the crowd." See details in Tailanga 2005
}

Thailand, 1964-1984 (Chaiprasathna 1996) studies the influence of surrealism on Thai artists and writers. The researcher finds that surrealist forms of expression and techniques were welcomed by artists and writers but its ideology and philosophy were ignored. Since the interest in surrealism in Thailand was not contemporaneous to the original movement in France, contact with surrealism was through art history courses and imported books. As a result, surrealist works in Thailand show a misinterpretation of the essence of surrealism.

Although only a few Thai writers and artists studied and comprehended the historical and conceptual aspects of any particular art movement, it is quite clear that they all were drawn to the new perception and expression of modernist art. This implies a crisis of representation in Thai literary circles. Thai writers and artists realized that they could not portray the world in the traditional, realist way any longer, hence the creation of innovative styles.

Several techniques of art movements are applied in Thai short stories; images of impressionism, ${ }^{21}$ expressionism, ${ }^{22}$ cubism $^{23}$ and abstract $^{24}$ were applied by writers to

\footnotetext{
${ }^{21}$ Usually impressionist paintings are not included in modernism but impressionist writings are (Childs 2000: 14).

${ }^{22}$ Expressionism depicts the subjective emotions that objects and events arouse. This aim is accomplished through the distortion and exaggeration of shape and the vivid or violent application of color (Atkins 1993: 98).

${ }^{23}$ Cubism emphasized the flat, twodimensional, fragmented surface of the picture plane, rejecting perspective and foreshortening in favor of geometric forms (Atkins 1993: 83).

${ }^{24}$ Abstract art explores the relationships of forms and colors and uses them in a non-
} 
offer readers non-traditional presentations. This shows that these writers lent importance to perception, not in the photographic realistic way, but rather in the fashion derived from the styles of art movements. The forms of expression derived from art movements show that Thai modernist writers, when seeking new approaches to writing, turned to art for creating new ways of expression.

\section{In Lonesome Wine in an Old-fashioned} Glass (ไวน์เปลี่ยวในแก้วโอลด์แฟชั่น) (written in 1965) by Suwanni Sukhontha, the protagonist looks out of a window and describes what she sees. She looks down and sees a jumble of rooftops. But her description turns the scene into the description of an abstract painting:

Those who didn't understand abstract paintings could simply look at these rooftops. The light blue galvanized metal rooftop, which was new, reflected the sunlight. Nearby was a rooftop of small red tiles. Over there were rooftops of large white tiles, of rusted galvanized metal sheets, of old tiles covered with velvet-like moss. What you saw was actually a painting. When a composite like this was on a canvas, it did not have to be about "something." Only colors are needed: white, rust red, moss green, all is arranged into a composition.

(Sukhontha 1982: 299)

In the above passage, the narrator looks at the rooftops and sees an extraordinary thing; the space before her becomes a huge canvas filled with colors of different

representational or subjective way (Atkins 1993: 43). shades and textures. Instead of describing the world as it is, the narrator conceptualizes it through the mind and transfigures it into the beauty of colors, shapes, textures and "composition" of an abstract art. Thus, the arrangements of form and color are intended to evoke the nonmaterial realm; this passage clearly shows the modernist concept of the work of art as an autonomous entity divorced from nature.

Thanong Phisan is another writer who uses expressionist images to convey the feelings of characters. His work, The Journey to the Inside (การเดินทางเข้าไปสู่ข้าง ใน), written in 1972, is told by three narrators who are close friends. Each narrator tells about his relationship with and his feeling for the other narrators. One of the narrators recounts an accident he witnessed:

One day, in the strong sunlight, I met a man at a crossing. He was an ordinary man like those that can be seen everywhere around me. We were waiting at the crossing; I looked at him meaninglessly. We started walking till we reached the island in the middle of the street, waiting to cross to the other side. Instead of moving forward, I stopped because the sunlight reflected from the white shirt of the man into my eyes. The man, walking ahead of me, was hit by a car; his body was thrown up high. His head struck the windshield and broke it; red blood was all over his shirt and the car. Red. I acted like other people in the city; I crossed the street without turning back and caught a bus. Later I got off the bus and walked in the strong sun. I saw a 
drop of blood on my sleeve. It spread out, bigger and bigger, red blood was everywhere. Then I started to vomit.

(Phisan 1972: 64)

Expressionist writers reject realism and go beyond impressionism to "objectify inner experience." They use external objects as transmitters of an internal mood. An unreal atmosphere, nightmarish action and distortion mark the feeling of characters (Holman and Harmon 1992: 187). In The Journey to the Inside (การเดินทางเข้าไปสู่ข้าง ใน), a drop of blood is immensely bigger in the narrator's mind after the accident has taken place before his eyes. The description of the pool of blood, then, signifies the horror in the character's mind rather than what he actually sees. This distortion emphasizes the effect of the accident upon the character. This style can be found in another work called Mali's Painting (ภาพเขียนของมาลี) published in 1970 by Khomson Khunadilok, where the nightmarish experience of "Mali" turns to madness; she paints a picture of the experience with her blood. The story is told from her point of view, exposing the distorted thoughts of the character's troubled mind.

Another form of art, the surrealist, can be found in many of Suchart Sawatsi's stories collected in Silence (ความเงียบ) (written in 1972) and Suwat Srichuea's War in the Grave (สงครามในหลุมฝังศพ) (written in 1975). Both writers offer surrealist images to present characters in dream-like states without conscious control, or their imagination and dreams. The surrealist form of expression can be found in numerous short stories, making it the most popular movement to be found in Thai literature.

Among the first stories to be presented in the surrealist style is Flight (หนี) which was written by Praphan Phonsavek in 1966 (Sawatsi 1975). The story is that of a killer who flees from the scene of a crime. He feels that someone is following him but when he turns to look, there is nobody. His fear increases and, because of hallucinations, he sees that he is being hunted by a big eye:

I saw it again, no body but an eye. A big eye floats before me, with gleaming light, revealing its vengeance. [...] But it was useless trying to run away from it because the even bigger eye was still following me. I couldn't take it anymore; I had to kill it.

(Sawatsi 1975: 22)

The whole story is a description of a state of paranoia. The reader does not know who the narrator is, why he kills a person and how. This new way of writing clearly emphasizes the mind of the protagonist rather than cause and effect which are the important features of the traditional narrative. The work ignores the plot structure of a beginning, a middle and an end, and the causal arrangement of the incidents. The reader gets into the mind of a mentally ill character and his hallucinatory experience is described in the surrealist manner.

In Silence (ความเงียบ) by Suchart Sawatsi, all the works in the collection show the flow of thought of the characters. For example, in $A$ Walk to the Field (การเดินทาง 
ไปยังท้องทุ่ง), the protagonist recounts his dreams:

I dreamed that I was walking to the fields, stepping on the green grass. Walking up the hill on a trail, I saw the sano plants on both sides. When walking down the hill, I felt the blood on my feet. The green grass was gradually covered with blood, and it was from my body. [...] My feet continued bleeding but I didn't feel any pain. Along the way, I was not quite sure that it was my blood I was stepping on.

(Sawatsi 1972: 122)

Like most stories of this period, it shows the flow of thoughts, including dreams, of the character. Hence, it emphasizes that the significant existence of human beings is to be found not in the outside world but in their minds. And the surreal dream of blood invites readers to investigate the character's frustration and repression. The story is, then, like an assemblage of memory, dreams, imagination, etc., of the protagonist, put together in a technique not unlike that of collage.

\section{Collage and montage as a representation of the chaotic cities}

The techniques of collage and montage, which are the placement of unrelated and fragmented images, became the new style of Thai modernist writers. A device typical of cubist paintings, collage is a technique employing disparate materials, such as cloth, wood and newspaper clippings, which are pasted together on a surface. In the early $20^{\text {th }}$ century, Picasso developed the style to defamiliarize the perception of these objects, as he put it:

If a piece of newspaper can become a bottle, that gives us something to think about in connection with both newspapers and bottles, too. This displaced object has entered a universe for which it was not made and where it retains, in a measure, its strangeness. And this strangeness was what we wanted to make people think about because we were quite aware that our world was becoming very strange and not exactly reassuring.

(Butler 1994: 167)

In cubist paintings, objects are not presented as whole; fragments of objects are imported into a picture with the purpose of forcing the viewer into an awareness of the strange and changing world.

Not only does cubism fracture objects into pieces but it also offers diverse perspectives; front, back and sides are seen simultaneously. All in all, cubist paintings allow the viewer to reconstruct and conceptualize the objects in new ways. This implies the crisis of representation mentioned earlier.

In literature, collage refers to words or passages that are not usually associated but which are put together to create a disturbing impact upon the reader. Usually found in modernist poetry, collage technique allows for an interpretive dislocation of words and phrases or verbal association. It also reinforces the strangeness of the images portrayed. Whereas montage, employed in filmmaking, is a method of rhythmically pacing shots, the rapid transition from shot to shot produces a particular effect, in 
literature it means a series of brief pictures, one following another quickly without any apparent order (Holman and Harmon 1992: 93, 301). Although collage and montage are the terms used in different media, they both refer to a fragmentary mode of representation. In this article, montage as a technique of film is thus included.

The fragmentary discourse of collage and montage cuts causal events into pieces and places them arbitrarily. These styles were quite new in Thai literary circles at a time when the unity of plot structure was a must for the short story.

The story that probably was the first to experiment with the collage technique is a work called On the Third-Class Railroad Car (บนรถไฟชั้นสาม) by Surachai Chantimathon. The story is of hectic scenes on a crowded train heading for Bangkok. It has no plot or development of the events that happen to particular characters. Rather, the narration is a compilation of the conversations of various groups of people on the train: a group of youngsters boasting about modern life in Bangkok, an employment agent promising to find a good job for a country girl, an old man and a young man discussing politics and criticizing the government and a sympathetic woman consoling a lonesome boy who has left home to find a better education in the big city. The compilation of the conversations of the various groups of people on the train is described in fragments; there is no connection between the people and the scenes. It can be compared with disparate objects being put together in one place, as in cubist paintings (Chantimathon 1996).

The scenes recounted in the story, though unrelated, can be interpreted as a criticism of the government's policy of modernization, which makes Bangkok the final destination and the center of all activities.

Silence (ความเงียบ) by Suchart Sawatsi is presented in a similar fragmented style. It uses the narrative style of drama, but the characters' thoughts are also presented between dialogues, making the style closer to that of the short story. The story begins with the scene of a woman and a man sitting in a canteen. She has just discovered that she is pregnant. She is seeking help from her male friend, but from the conversation, he apparently does not particularly care and is quite irritated by the woman's problem. Then the scene shifts to a waiter who is busy finding the right station on a radio; he has lascivious thoughts when he sees a nude poster and hears obscene songs. He also thinks about the customers, who are mostly students, and he watches the woman and the man in the canteen. Then, a voice from the radio is heard, reporting the situation in the Vietnam War and the government's propaganda condemning leftists and communists. Next come the disorderly thoughts of a student who wants to be a writer. He looks at a woman (presumably the same woman who is mentioned earlier in the story) and thinks that she might become a character in his novel. The story ends with the voice from the radio reporting the number of casualties in the Vietnam War (Sawatsi 1972).

The scenes presented are barely connected; the only relation is that the characters are sitting in the same place. The fragments of the scenes: the conversation between the man and the woman, the thoughts of the waiter, the thoughts of the student, the news of the Vietnam War, are like different materials pieced together in a space. The canteen, then, can be compared with a canvas on which unrelated 
materials are pasted. The story shows the ignorance of the Thai people about the Vietnam War because everyone is busy with his/her life while the tragic war in Vietnam continues.

The story is also a criticism of the policy of the Thai government who cooperated with the United States and became involved in the war.

Another example of collage is Filth (โสโครก) written by Thongchai Surakan (Surakan 1972). The narrator is waiting for a bus late at night and thinking about the hypocrisy of the older generation. $\mathrm{He}$ thinks he is being forced to become materialistic, so he wants to go away. To kill time he reads a newspaper. So the story moves forward with the news and the articles he reads: President Nixon of the United States visiting China, the attack of communists in a village in Thailand, news of high society, readers' complaints about the economy and corruption, readers' letters seeking advice on their love life, U.S. operations in Vietnam War and casualties in Vietnam. Then a street cleaner comes by and he and the narrator have a brief conversation about life. The narrator decides to go back and throws the newspaper in the trash.

Similar in content and style to Silence (ความเงียบ), Filth (โสโครก) is not only a criticism of the Vietnam War but also of the government and the social and economic malaise. The technique of collage in this story is quite apparent since the fragments are taken from news reports and articles in the newspapers.

The narrative of the short story Complexity and Confusion (สนสับ สับสน) by Kon Krailat is presented in a similarly fragmented way. But the technique of montage provides the narrative structure.

Complexity and Confusion (สนสับ สับสน) is about a chaotic city: boys running up and down the streets selling newspapers, female passersby in short skirts, a crippled beggar, a dirty stray dog, a group of intellectuals drinking and cursing the unfairness of the country, teenagers disappearing into a department store that sells foreign goods, a cinema showing an American film with an obscene and immoral subject, a traffic jam, a body falling from a moving bus and the voice of a mother consoling her child. All become connected by forming the scenes through which an old experienced woman walks. The story is an implicit criticism of the change of Bangkok due to modernization since the story "shows," and does not "tell," these chaotic and modern states (Krailat 1972).

Thus, the story has no plot. The shots following on one after another can be described as montage because they are only the collection of scenes portraying the chaotic life of Bangkok witnessed by the indifferent old woman.

Montage can be found in From the UrineColored Room (จากห้องสีปัสสาวะ) written in 1973 by Thanong Phisan (Sawatsi 1975). The story relates the confusing thoughts of the protagonist, who feels alienated from his job and the town he works in. His thoughts, which are about the question of who he is, his beloved friends, his loneliness, excerpts from books and films, an image in his imagination of a woman covered with blood, a water buffalo sunbathing in a pool of mud, etc., are unrelated fragments and yet are mostly 
intelligible, except, however, for the passage at the end of the story:

The field under the strong sun. The water buffalo in the pool of mud. The smile of the victor. The urine rapidly flows and smells in the model drainage pipes. A fair equality. [...] A girl with dull skin and unkempt hair sits on the back of a buffalo singing a lively air. I spit and curse. Double standard. Vira walks along the canal slowly. It will show the meaning if it finally happens. Don't let it die like that. I sit against the wall. Like something is haunting this room.

(Sawatsi 1975: 246)

It seems that these fragments of thoughts, which occur at the beginning of the story, appear again rapidly one after the other at the end of the story to create a film-like impression for the reader. Thus this might be interpreted as the technique of montage. The technique used implies the shattered self of the protagonist living in an alien world.

In a work called The Index Finger in the Third-Class Car (นิ้วชี้ในตู้ชั้นสาม) by Suwat

Srichuea, montage technique is used, presenting unusual imagery. The story is about a young man who goes back home to enlist in the Army. On the train he encounters a group of wild rowdy soldiers who dare him to drop a knife in the space between his index and middle fingers. He accepts the dare and it causes him to lose his index finger. Then they suggest playing Russian roulette but before a bullet is shot through someone's head, the gun is pushed away. The young man hurriedly jumps off the train and decides not to go back home. The beginning of this story relates what he sees through a window:

The 6.30 p.m. The BangkokUbonratchathani train pulled out of Hua Lumpong station. I sat in a third-class car after putting my cloth bag on the rack above the seat. I was watching Bangkok from a window; it was like I was watching a film. The first second, I saw people waving; the fifth, the train left the people behind, [...], the next second, a twenty-story building moving fast and then followed by slums; the $200^{\text {th }}$, the train running past a prison, the next second, passing the Liberty Monument and an army camp, the $1649^{\text {th }}$, people along the track throwing stones at the train.

(Srichuea 1975: 73)

The beginning of the story foreshadows the violence the protagonist will encounter later on. The pictures he sees signify conflict: contrast (a high building-slums), crime (prison), war (monument and camp) and violence (thrown stones). But instead of describing the scenes in the traditional way, the writer uses film techniques to offer new imagery.

The urbanization of Thailand undermines the sense of continuity. This continuity is derived from the rhythms and the simplicity of rural culture. The chaos and the complexity of modern life makes the writers conscious of writing in a period of transition and crisis. Since the experimental 1964-1973 Thai short stories are mainly about the cities, it is apparent that the writing techniques which are capable of portraying the strains and tensions inherent in city life are collage and montage. 
Modernist Thai Short Stories

These features are consistent with modernism, since collage and montage are considered the art forms of modernism, for their fragmentation portrays the disorder and chaos of cities (Eysteinsson 1990: 151).

It may be concluded here that modernist Thai writers use the techniques of collage and montage to imply the malaise of modern society, the shattered self and a criticism of the autocratic administration.

\section{Conclusion}

A study of the relationship between modernist Thai short stories from 1964 1973 reveals that most writers who wrote in modernist experimental styles were either graduates of art schools or those who were personally interested in art. Their background in art helped them to adapt the techniques of visual art to their writings.

Thai short stories from 1964 to 1973 display a radical change because the crisis of representation was realized. These modern Thai writers found themselves at odds with their contemporaries and increasingly felt that to describe the modern and changing Thai society, different styles were required in their works. The search for innovation was successful when the techniques of modern art were modified for use in written texts. Since, in some respects, modernist art represents the modern world as chaotic and shattered, this search for innovation in Thai modernist short stories is thus inseparable from the search for new values in modern life.

\section{References}

Atkins, Robert. 1993. Art Spoke. New York: Abbeville Press.

Bradbury, Malcolm and James McFarlane. 1985. Modernism 1890-1930. New York: Penguin Books.

Butler, Christopher. 1994. Early Modernism: Literature, Music and Painting in Europe 1900-1916. Oxford: Oxford University Press.

Chaiprasathna, Sodchuen. 1996. Surrealistic Trends in Painting and Literature in Thailand, 1964-1984 (จิตรกรรมและวรรณกรรมแนวเซอร์เรียลิสต์ใน ประเทศไทย พ.ศ. 2507-2527). Bangkok: The Siam Society. (In Thai)

Chantimathon, Surachai. 1996. From the Plateau (มาจากที่ราบสูง). $10^{\text {th }}$ edition. Bangkok: Samanchon. (In Thai)

---. 1997. Where Are We Going? (เดินไปสู่ หนไหน?). $10^{\text {th }}$ edition. Bangkok: Samanchon. (In Thai)

---. 1997. Visited by Madness (ความบ้ามา เยือน). $10^{\text {th }}$ ed. Bangkok: Samanchon. (In Thai)

Chiangkun, Vittayakon. 1990. So I Came to Find the Meaning (ฉันจึงมาหา ความหมาย). $10^{\text {th }}$ edition. Bangkok: Samanchon. (In Thai)

Childs, Peter. 2000. Modernism. New York: Routledge. 
Department of Fine Arts. 1993. 73 Thai Artists from Silpa Bhirasi School (73 ศิลปินไทย ศิษย์ศิลป์พีระศรี). Bangkok: Contempus. (In Thai)

Edson, Laurie. 2000. Reading Relationally: Postmodern Perspectives on Literature and Art. Ann Arbor: University of Michigan Press.

Eisenman, Stephen. 1997. Gauguin's Skirt. London: Thames and Hudson.

Eysteinsson, Astradur. 1990. The Concept of Modernism. Ithaca: Cornell University Press.

Harrison, Charles. 1997. Modernism. London: Tate Gallery.

Holman, C. Hugh, and William Harmon. 1992. A handbook to Literature. $6^{\text {th }}$ ed. New York: Macmillan.

Karl, Frederick R. 1985. Modern and Modernism: The Sovereignty of the Artists 1885-1925. New York: Atheneum.

Khunadilok, Khomson. 1992. A Walk in a Night (การเดินทางในคืนวันหนึ่ง). Bangkok: Samit. (In Thai)

Krailat, Kon. 1972. Golden Flowers (ดอกไม้สีทอง). $2^{\text {nd }}$ edition. Bangkok: Phan Fa Phittaya. (In Thai)

---. 1974. The Memoir of a Man Called Pueng (บันทึกของคนแซ่เพือง). Bangkok: Non. (In Thai)

Lewis, Pericles. 2007. The Cambridge Introduction to Modernism.
Cambridge: Cambridge University Press.

Phisan, Thanong. 1972. The Journey to the Inside (การเดินทางเข้าไปสู่ข้างใน). The Social Science Review. 10.3: 62-71. (In Thai)

Pholanan, Thanya. 2003. The Roads to the Clouds (ถนนไปสู่ก้อนเมฆ). $7^{\text {th }}$ ed. Bangkok: Kwankhaw. (In Thai)

Phongphaichit, Phasuk, and Chris Baker. 2003. Thai Political Economics in the Bangkok Period (เศรษฐกิจการเมืองไทย สมัยกรุงเทพฯ). Chiangmai: Silkworm. (In Thai)

Roston, Murray. 2000. Modernist Patterns in Literature and the Visual Arts. New York: New York University Press.

A Collection of Short Stories by Num Nao and Prachan Siaw (รวมเรื่องสั้นโดยหนุ่ม เหน้าและพระจันทร์เสี้ยว). 1971. Bangkok: Praphansan. (In Thai)

Russell, John. 1981. The Meanings of Modern Art. New York: Harper \& Row.

Sawatsi, Suchart. 1972. Silence (ความเงียบ). Bangkok: Nangsue. (In Thai)

---. (ed.). 1975. The Road That Led to Death (ถนนสายที่นำไปสู่ความตาย). Bangkok: Duang Kamon. (In Thai)

Schwarz, Daniel R. 1997. Reconfiguring Modernism: Exploration in the Relationship between Modern Art and 
Modern Literature. New York: St. Martin's Press.

Srichuea, Suwat. 1975. War in the Grave (สงครามในหลุมฝังศพ). Bangkok:

Praphansan. (In Thai)

Steiner, Wendy. 1982. The Color of Rhetoric: Problems in the Relation between Modern Literature and Painting. Chicago: University of Chicago Press.

Stevenson, Randall. 1992. Modernist Fiction: An Introduction. Lexington: University Press of Kentucky.

Sukhontha, Suwannee. 1982. Being Left Alone in a Cold and Starry Night (คืน หนาวที่เหลือแต่ดาวเป็นเพื่อน). Bangkok: Duangta. (In Thai)

Surakan, Thongchai. 1972. Filth (โสโครก). The Social Science Review 10.9: 82-87. (In Thai)

Tailanga, Irrawadee. 2005. Life in Agony: The City as Portrayed in the Modernist Thai Short Stories (1964-1973). MANUSYA: Journal of Humanities, Special issue 10: 88-106.

Torgonick, Marianna. 1985. The Visual Arts, Pictorialism, and the Novel. Princeton: University of Princeton Press. 